\title{
PROPOSING A HOLISTIC BASIN-SCALE AS A STRATEGY OF SMART PLANNING IN ADAPTATION TO CLIMATE CHANGE
}

\author{
CENK HAMAMCIOĞLU \& ZEKIYYE YENEN \\ Faculty of Architecture, Department of Urban and Regional Planning, Yıldız Technical University, Turkey
}

\begin{abstract}
Forthcoming expected results due to the phenomenon of global warming require adaptation strategies and precautions promptly to be taken on international, national and local scales. With reference to this urgent circumstance, policy frameworks executed by the international organizations, governments and ministries of nations on the consequences of adaptation to climate change have been on the agenda over the last decade. This study is derived from Turkey's policy of approach that excludes the investments of infrastructure and economic sectors from the scope of the National Climate Change Adaptation Strategy and Action Plan (2011) as a critic from the perspective of balanced development that is also an instrument of sustainability. Therefore, to clarify this deficiency, factors of infrastructure and economic sectors exacerbating the process of climate change and their mutual interaction with other sectors and nature is identified and discussed over remarkable samples from three geographically and socio-economically different basins in Turkey, studied since 2005 by the researchers of this paper. In order to coordinate adaptation to climate change, this study designates: (1) the essential role of water-soil-vegetation integrity of the life cycle with human activities, (2) controllable and observable scale for the management of risks and hazardous events, (3) opportunity to determine capacities and thresholds based on cross-sector interaction in terms of the characteristics of the local natural environment and (4) co-existence of communities and settlement system patterns sharing a fate of union of particular bases for implementing holistic basinscale as a strategy of smart planning. As a result, compelling impacts of climate change once again verify and remind us of the significance of interdisciplinary and holistic political decision-making and modules that should involve all sectors in the strategy of smart planning for the future.
\end{abstract}

Keywords: climate change, basin scale, strategy of smart planning.

\section{INTRODUCTION}

According to IPCC report (2014), global climate temperature is predicted to increase between $1.4^{\circ}-5.8^{\circ} \mathrm{C}$ until the end of century unless measures are taken to critically reduce emissions. This means that globe's hydrological cycle will render unstable and uncertain extreme disasters such as sea level rise, coastal erosion, droughts and floods.

Heretofore, in case of the scope of Turkey's Adaptation Strategy and Action Plan (2011) prepared in the framework of UNFCCC is restricted with water, agriculture, food, ecosystem services, bio-diversity, forestry, disaster risk management and public health. However, it is inevitable that consequences of similar changes will also affect many infrastructure (energy, transportation, etc.) and economic (tourism, logistics, etc.) sector activities that benefit from, influence and draw changes on nature and other sectors are required to be included.

This study aims to discuss significance of new opportunities for sectors in terms of balanced development as an instrument of sustainability in the context of adaptation but also determining different sectorial investments by anticipating impacts of climate change through sample basins in Turkey. The most important reason for this is, the regional/local planning unit scale of basins that imply communities sharing common past-present-future and interventions possessing positive or negative consequences for the rest of it. Such that 
these units based on natural phenomena are also environment for the holistic smart planning.

Following the methodological approach of this paper, problem considering the expected impacts and factors of climate change will be explained in charge with the stage of climate change adaptation and scenarios referring future climate conditions in Turkey. This enlightenment will be thoroughly debated over examples from Bakırcay, Goksu and Anatolian side of Istanbul basins where the symptoms of climate change gain momentum in terms of infrastructure and economic activities. The critical role of basins as units of holistic approach for smart planning in adaptation to climate change will be demonstrated and strategies will be assessed at the final.

\section{METHODOLOGY - CONCEPT OF "HOLISTIC BASIN-SCALE” IN CO-OPERATION WITH "SMART PLANNING"}

In this study, a multi-factor approach is adopted corresponding to the facts briefly explained below:

- Determination of the scale of study evolves out of the basin-based definition of the planning units (NUTS-Nomenclature of Units for Territorial Statistics) that the Turkish State Planning Organization has put into practice since more than a decade;

- The selection of geographical regions that are predicted to be the first and mostly affected from the climate change in Turkey on behalf of scientific studies and at the same time the inclination to three different basins (Göksu Basin that opens to the Eastern Mediterranean/Southbound, Bakırçay Basin that reaches to the Aegean Sea/Westbound, the Anatolian side of Istanbul basin that meets the Black Sea/Northbound) in terms of their characteristics besides investments;

- The studies on three basins including research projects [1]-[3], undergraduate and graduate projects at the Department of Urban and Regional Planning of Yildiz Technical University [4] and publications [5], [6].

The basins' philosophy and their cycle of nature revealed starting point of this paper. In one hand, basins offer a variety of potentials according to their geographical characteristics and on the other hand, socio-cultural environments in terms of geographical units of life. However, any type of interference in any part of a basin displays positive and/or negative impacts on the rest of it. For these reasons, basins received cognizance as planning modules following the European Union standards of "NUTS" approach that is also adapted by the State Planning Organization to Turkey. In fact, the economic activities (agriculture, livestock, industry, tourism etc.) and investments (water canals, dams, power plants, infrastructure and transportation projects such as roads, ports, railways, etc.) to change the traditional production techniques inevitably affect employment conditions, comforts of life and accessibility. Doubtless, these human based interferences generate changes over environmental attributes; while the quality of these changes entail prior factors over the future of the whole economy (in return). And in the case of deterioration of natural environment and social values, that are sources of peculiar environment, cannot enable the role of sustainable life that based on "preserving and developing".

Bearing these fundamentals in mind, the objective of the study intends to link settlement pattern and economy with the basin-scale approach which have the possibility to play a vital tool for the elimination of multi-dimensional disparities, poverty and other deficiencies where the settlements share common physical environment, but different in 
potentials and degradation. Moreover, the basin-scale approach could also have possible substantial outcomes against the impacts of economic activities on the climate change and their results. On one hand, the researchers' recent case studies concerning the basin-scale approach, on the other hand, the potentials of distinctive peculiarities for tourism and the types of other investments influenced nomination of the topic and choice of samples.

\section{FACTORS OF CLIMATE CHANGE IN DIFFERENT BASINS}

The Mediterranean Basin, where Turkey is also located, is designated as one of the most vulnerable regions of the earth against expected impacts of climate change in the IPCC report [7]. Turkey has joined the United Nations Framework Convention on Climate Change in 2004 and signed the Kyoto Protocol in 2009. However, in the year 2023, Turkey's energy demands foreseen to reach twice the 2011 figure, while no reduction target for greenhouse gas emissions for Turkey is set. Meanwhile, fossil fuels (coal, oil and natural gas), nuclear energy and hydroelectric power plants are defined as sources to meet energy demand. What is more, in the projections of Turkish Ministry of Energy it is envisaged that, utilization of imported and domestic coal will increase more than $200 \%$ and petroleum $100 \%$ by 2020 .

The data, prepared by the Turkish Ministry of Forestry and Water Affairs General Directorate of Meteorology with a reference period of 1961-1999 years, that is taken into account in the National Climate Change Adaptation Strategy and Action Plan [8], and the $6^{\text {th }}$ National Declaration of the Climate Change in Turkey [9] which taken the period of 1971-2000 as a reference for Turkey's regional climate projections are discussed in three phases; up to 2040, from 2041 to 2070, and from 2071 to 2099. If these projections that are summarized roughly in Table 1 are assessed, it will be noticed that increase in surface temperatures will influence particularly after 2040. Surface temperatures in all regions are expected to reach $5-6^{\circ} \mathrm{C}$ after 2071. In the Aegean, Mediterranean and South-eastern Anatolia regions, the winter precipitation will decrease by $20-50 \%$, while the Black Sea coast will encounter risk of hazardous floods and landslides caused by the heavy rainfall.

Table 1: Regional Climate Projections in Turkey (benefited from Turkey's National Climate Change Adaptation Strategy and Action Plan, 2011, 6th National Declaration on Climate Change in Turkey, 2016).

\begin{tabular}{|c|c|c|}
\hline Period & Surface Temperature & Precipitation Percentage \\
\hline $\begin{array}{l}\text { until } \\
2040\end{array}$ & $\begin{array}{l}0.5-1^{\circ} \mathrm{C} \text { in winter, } 1-3^{\circ} \mathrm{C} \text { increase in } \\
\text { all regions in spring \& summer }\end{array}$ & $\begin{array}{l}\text { Decrease in rains in most regions, only } 30 \% \\
\text { increase along the Black Sea coasts during } \\
\text { summer }\end{array}$ \\
\hline $\begin{array}{l}2041- \\
2070\end{array}$ & $\begin{array}{l}1.5-3^{\circ} \mathrm{C} \text { in winter, } 3-4^{\circ} \mathrm{C} \text { rise in } \\
\text { summer \& spring, increases will } \\
\text { become more prominent in Eastern, } \\
\text { South-eastern \& Central Anatolia } \\
\text { and Mediterranean regions during the } \\
\text { summer months }\end{array}$ & $\begin{array}{l}30 \% \text { decrease in Central \& Eastern Anatolia in } \\
\text { summer, } 150-200 \mathrm{~mm} \text { decrease during the } \\
\text { winter in South-eastern Anatolia, in particular } \\
100-200 \mathrm{~mm} \text { increase along the Black Sea } \\
\text { coasts, } 20 \% \text { decrease in rainfall except Black } \\
\text { Sea region in the spring and decrease in all } \\
\text { regions in autumn }\end{array}$ \\
\hline $\begin{array}{l}2071- \\
2099\end{array}$ & $\begin{array}{l}2-4^{\circ} \mathrm{C} \text { increase in winter in West \& } \\
4-5^{\circ} \mathrm{C} \text { in Eastern Anatolia, } 3^{\circ} \mathrm{C} \text { in } \\
\text { summer in Marmara \& Black Sea, } 4- \\
5^{\circ} \mathrm{C} \text { in Eastern Anatolia, } 6^{\circ} \mathrm{C} \text { in } \\
\text { South-eastern Anatolia, } \\
\text { Mediterranean \& Aegean regions }\end{array}$ & $\begin{array}{l}\text { In the spring, all regions except the Black Sea } \\
\text { coasts decreased by } 20 \% \text { in rainfall and by } \\
40 \%(300 \mathrm{~mm} \text { and over) in summer \& autumn, } \\
10 \% \text { increase along the Black Sea coasts } \\
(250-300 \mathrm{~mm}) \text { and North-eastern Anatolia } \\
(100 \mathrm{~mm})\end{array}$ \\
\hline
\end{tabular}


This table, emerged from the scenarios, demonstrates that in a near future, Turkey will get hotter, more arid and uncertain in terms of precipitation patterns. Depending on the fall in precipitation, Turkey will be exposed to impacts on the consumption and reduction of underground and surface water resources, forest fires, drought and desertification, loss of biodiversity and deterioration of ecological balance, as well as a loss of agricultural productivity and decrease in tourism revenues. According to Turkey's $5^{\text {th }}$ National Communication under the UNFCCC [10] the Central, Mediterranean, Aegean and Marmara regions will face with water stress from 2030 onwards due to the estimated population to reach a hundred million.

National Climate Change Adaptation Strategy and Action Plan (2011) have focused on five significant vulnerable fields (water resources management, agricultural sector and food security, ecosystem services, biodiversity and forestry, natural disaster risk management and public health) in the context of predictions of regional climate projections. However, in the face of high risk, if measures are applied without calculating the charges and deliveries, it is very likely that severity of climate change will be prompt in regional and local scales; hence, infrastructure and economic investments that include and conduct land use decisions are excluded from the scope of the adaptation strategy and action plan. Moreover, infrastructure and economic investments are the beneficial initiatives that profit and interact directly with the vulnerable category fields identified and focused in the National Climate Change Adaptation Strategy and Action Plan. In addition, one of the most important consequences of the global climate change is sea level rise and coastal erosion. Therefore, coastal regions, river basins and deltas are the priority areas at risk.

Moving from here, in this part of the paper primarily, the basins are briefly introduced. And then the impacts of infrastructure and economic investments in case of the basins (the Göksu basin connecting inner Anatolia to Mediterranean which includes a delta protected by International Ramsar Convention, the Bakırçay basin in West Anatolia and Anatolian side of Istanbul basin oriented towards the Black Sea covering a shore land and water through which includes a natural site) from Turkey pointed out in Fig. 1 are explained, taking the sea level rise study results of Kuleli [11], Kuleli et al. [12], Alpar [13], Demirkesen et al. [14] for Turkey into consideration. Subsequently, the implications of infrastructure and economic investments being applied and/or envisaged at regional and local scale and their reciprocal interactions with the natural (water, air, soil, etc.) and built environment in the context of regional and local climate change will be investigated.

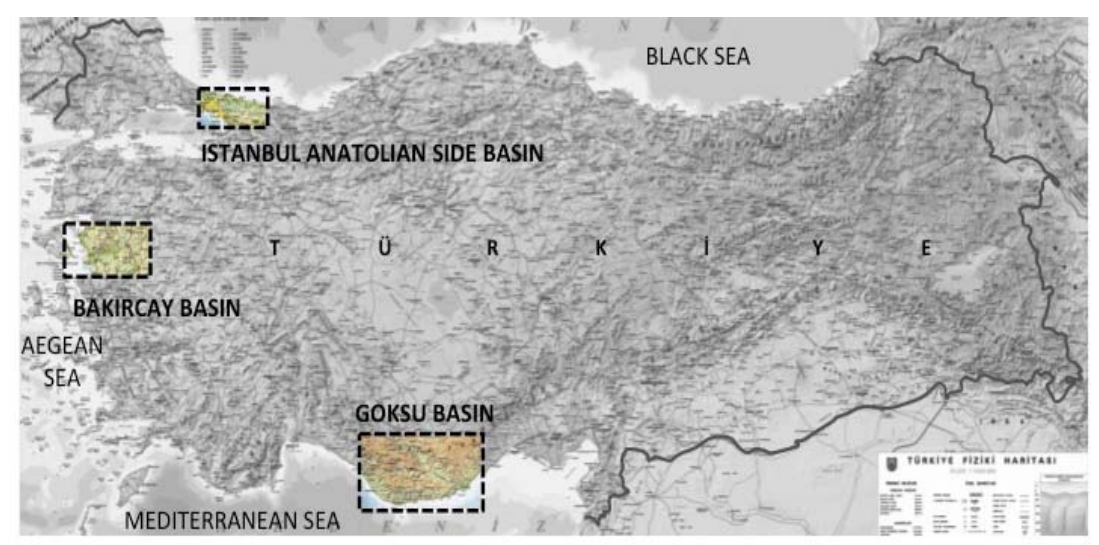

Figure 1: The location of Exemplified Basins in Turkey. 
The Göksu Basin consists of three sub-regions. The first sub-region embraces a delta, plain and coastal shore dominated by the Mediterranean climate connecting the Mediterranean and Central Anatolia regions with a characteristic natural access corridor where the percentage of slope is lower than $10 \%$, agricultural production is appropriate with irrigable land structure and the settlements are concentrated. The second sub-region composed of mountainous areas, where the transportation facilities are reduced at both sides of the valley, irrigation potentials are limited, forest villages are concentrated, and livestock and dry farming activities take place. And the third part of the basin involves the transition to Konya Basin where the accessibility conditions get weaker due to the rough nature of topography, dominated by terrestrial climatic conditions and receive the least amount of rainfall in the basin, source of income is provided by livestock, and encounter severe erosion problems (Fig. 2).

The Bakırçay Basin is situated near the provincial centres of Izmir, Manisa and Balıkesir with proper transportation facilities and port connections due to the open geographical location where the ancient Pergamum settlement had been founded in the Northern Aegean part of Turkey. The centre of the Bakırçay Basin is Bergama and its entire surrounding, where rich agricultural raw materials are processed, special local products are marketed, and a variety of requirements for rural settlements are manufactured. Dikili is the gate of the Basin from the sea with a passenger and freight port leading to the region in terms of local tourism with the sandy beaches extending towards the north and an indented coastline along the Çandarlı Bay in the south. The Basin is circumscribed by the Madra Mountains, where the Kozak Plateau is situated offering potentials for rural tourism, nature and highland tourism at the north and Yunt Mountains at the south (Fig. 3).



Figure 2: The Goksu Basin - Potentials, Problems/Risks. 


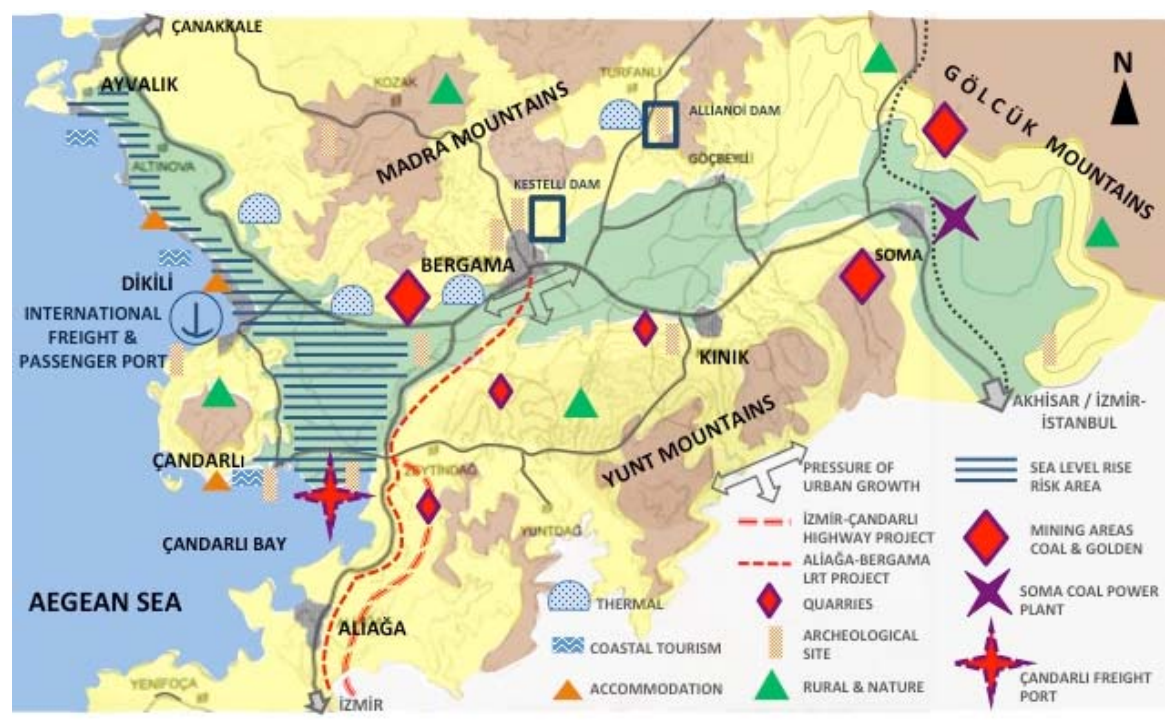

Figure 3: The Bakırçay Basin - Potentials, Problems/Risks.

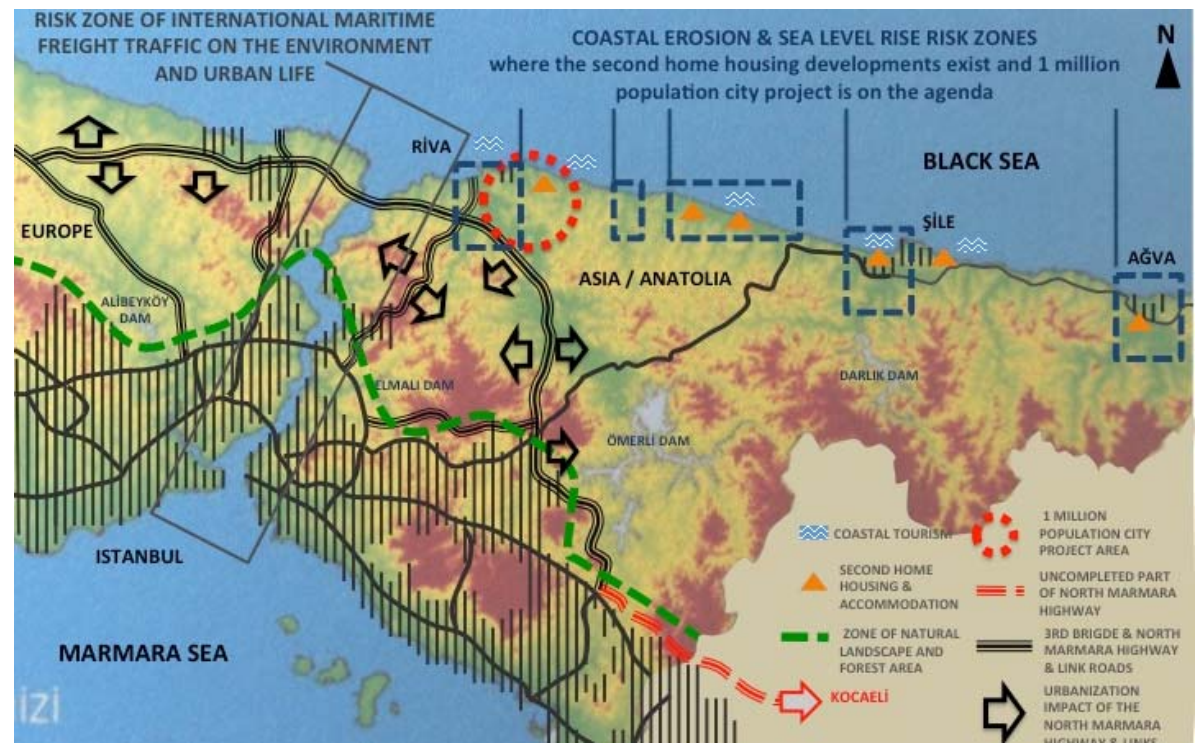

Figure 4: Anatolian side of Istanbul Basin - Potentials, Problems/Risks.

Anatolian side of Istanbul basin covers the coastal areas in the Bosphorus and the Black Sea at the north of Istanbul Metropolitan Area including forests, large and small valleys and rural settlements. This basin possesses very critical features with its respiratory and drinking water sources for the requirements of metropolitan population of Istanbul comprising a countryside and forest area adorned with diversified assets of wild life and vegetation between the Black Sea and Mediterranean climates providing recreation, strolling, sports and different water activities (Fig. 4).

The expected impacts of climate change in the exemplified basins are discussed in the 
context of the activities carried out, potentials, challenges and risks firstly on behalf of the sea level rise and then the activities stimulating the climate change point of views.

\subsection{The impacts of sea level rise due to climate change on the infrastructural and} economic investments

Principally, sea level rise will put densely populated coastal regions and settlements increasingly at risk. For example, the Silifke district centre, Tasucu, Atayurt, Atakent, Arkum and the rural settlements in the Göksu Delta will be directly affected by the increasing sea level in the Göksu Basin where the approximate winter population is 70 thousand according to the TÜIKK [15] data. The similar consequence applies to the settlement of Dikili and Çandarl, which are located on the Aegean Sea coast of the Bakırçay Plain inhabiting a total winter population of over 40 thousand according to TÜIKK [15] data. In addition, it is understood that in these settlements where both basins are opened to the sea, summer populations become 5-6 times higher than winter populations and that there will be more populations to be affected by the sea level rise. Therefore, the rise of sea level only in these two basins reveals a situation that directly concerns about half a million people today. And the sprawl of the metropolitan area towards the Istanbul Anatolian side of basin that is diverse with large and small rivers orienting to the Bosphorus and the Black Sea coasts draws a major threat to the existing rural settlements and small towns located at this recreation area of Istanbul.

On the other hand, some parts of the alluvial plains, that are limited in size in the mountainous geography of Turkey, will be exposed to flood during the process of sea level rise. Such a case will affect the agriculture-based economy and industry as well as the population that is constantly boosting the pressure on farm fields and agricultural areas. As a matter of fact, the plain behind the Göksu Delta is rich in cultivation of sesame, tomatoes, strawberries, apricots and various citrus that yields several times a year at a rate between $10-50 \%$ of Turkey and the Bakırçay plain covers a territory that possesses a proper and convenient environment to proceed the most precious cotton in terms of quality in the World, as well as vineyards and industrial plants such as tobacco and olives. From this point of view, the rural areas of Istanbul, which have already very limited agricultural lands, are likely to disappear, as if they are typical of the environmental landscape of the metropolitan city.

In terms of economic activities, tourism is one of the sectors where the sea level rise will mostly affect. Convenient location and well-developed road network facilities, rich cultural (ancient city of Pergamum, Asklepion, Roman Basilica, several ruins and health-thermal destinations, resources for coastal tourism, nature-based activities in a wide variety of landscape) and mostly preserved rural resources (Ramsar Convention Area in the Göksu Delta, authentic villages etc.) provide both several possibilities for the local people and alternative destination spots in the Bakırçay and Göksu basins. These basins have different cultural, folkloric features and authenticities due to their special geographies. However, tourism activities in Turkey, notably supported by state incentives since 1980s, have been aimed at meeting mainly mass (sea-sand-sun focused) tourism demands in the summer seasons due to climate characteristics of the regions. For this reason, star hotels including package tours and second home housing (holiday villa) areas mainly used by the local tourists continue to develop in coastal zones and coastal settlements with sandy beaches. Therefore, the increase in sea level will have a direct negative impact on the Göksu Delta and high-density second home housing areas and accommodation facility investments ongoing at the immediate surrounding. These impacts will also expose its affects at the 
Bakırçay Basin of the longest and cleanest beaches of Anatolia extending to the north of Dikili and the coastal zone including the second home housing areas, accommodation facilities and villages. At the same time, the developing second home housing areas and tourism investments along the coastal and plain areas of Çandarlı settlement will also suffer.

The rise in sea level will also affect infrastructure investments that are being built or planned on the coast and in the delta areas where the basins meet the sea. One of these investments is the İzmir-Çandarlı North Aegean Port at the delta area of Bakırcay Basin as the largest container port of Turkey with a 12 million TEU (twenty-foot equivalent unit) capacity and planned to be completed in 2018. The planned project to provide regional railway and road highway (İzmir-Çandarl1) connections with the port will have a negative impact on the natural environment quality, delta life, marine and agricultural lands (tourism resources) as well as the ancient settlement of Elaia next to that will be threatened also by the expected sea level rise. The Mersin-Akkuyu Energy Terminal is another example of investment that is planned to be completed in 2023 and is estimated to meet $6 \%$ of Turkey's electric energy, but will be at risk due to its location on the seashore. Although this energy terminal is located outside the Göksu Delta, it will be directly affected by the level rise of the water due to its location on the seashore, and it is an investment decision that will risk the natural, social and economic life of a greater area.

\subsection{Infrastructural and economic investments stimulating climate change}

There are plenty of economic activities (greenhouse, industry etc.), irrigation and energy investments (dams, hydroelectric plant - HEP irrigation canals, nuclear power plant), rapid urbanization, and land oriented freight-passenger transportation investments increasing energy consumption and stimulating climate change.

The dams are constructions to save up water in order to irrigate agricultural lands, to use in industries and to supply drinking water while the hydroelectric power plants are built to generate energy. However, both are large-scale investments enforcing the environment and local climate in multiple extensions. Depending on the volume of retained water, dams moderate local climate and increase humidity, where they also designate adverse symptoms on the local agricultural products. At the same time, they usually remain the settlements and cultivable lands under threat of reservoir, displacement of locals, and detriment of vegetation and habitats of wildlife, accumulation of organic materials emitting methane gas to the atmosphere. On the other hand, river type of hydro-electric power plants generating energy by spilling water from a distant elevation to return water turbines entail alteration in streambeds, flow of rivers damaging the ecosystem in the basins. Moreover, they also prompt woodcutting during the construction of transmission tunnels, access roads that corrodes the nature. For instance, in case of Göksu Basin there are three dams (Gezende, Ermenek and Bağbaşı) operating and four dams (Bozkır, Afşar, Mut, Kayraktepe) under construction nearly covering 30,000 hectares. While the Bağbaşı, Bozkır and Afşar dams are constructed as a part of Konya Plain Project that aims to provide water to irrigate the inland basin of Konya via a tunnel (Blue Tunnel Project with a length of $17 \mathrm{~km}$ ), these projects will eliminate the water regime for the rest of basin and put the delta under the protection of Ramsar Convention at risk. On the other hand, the construction of Mut and Kayrektepe dams will affect the socio-economic rural livelihood and approximately 10,000 rural populations will be removed and unoccupied. Also considering the on-going and proposed projects of river type hydroelectric power plants will reach 19 only in the Göksu Basin. In fact, these irrigation and energy investments frequently located with the decisions 
of central government that change the structure of river flow regimes in the ecosystems of water basins and strike a blow against the economic and social life cycle at the same time. These radical changes mean also the loss of peculiarities subjecting tourism and agriculture in return as well.

Other economic investments stimulating the climate are the intensive development of greenhouse facilities that spread larger areas on cultivable lands. Although greenhouses allow for greater control over the agricultural products, they display similar impacts and characteristics with industrial facilities in terms of leaving harmful fossil gases warming the atmosphere during heating induced emissions. At the same time, greenhouses lead heat islands while storing and reflecting sunrays on the surface. Today, greenhouse facilities are mostly concentrated along the Mediterranean coasts and valleys' of Göksu Basin even Göksu Delta (the day we passed, a fire broke out in the Delta due to the greenhouses, the fire brigade could not intervene due to the marsh ground structure, and the wetland of more than 300 of the bird species in Turkey was lost) and become an increasing economic activity in the Bakırçay Basin close to the thermal energy sources in order to utilize necessary heat for the cultivated products.

Energy consumption in residences consumes $25 \%$ in Turkey [16]. Since the rapid population growth of urban areas in the three basins continue, basic natural conditions such as duration of sun, wind and orientation do not take into account on energy-consuming (heating and cooling) systems [17]. In the meantime, sprawl of cities lacking sufficient open and green spaces evolve into completely large portions of heat islands as well. Also, the energy consumption of motor vehicles and their share in carbon gas emissions occupies $18 \%$ in Turkey. Relatively, the major national highways in the three basins compared to insufficient development of maritime transport and lack of railways, the hegemony of highway transportation network makes it one of the competing factors contributes to climate change. In case of Göksu Basin, widening of roads and tunnel constructions between Silifke-Antalya highway, Akkuyu Nuclear Power Plant access roads and 1/100,000 Environmental Plan, the dominance of highway transport appears to continue. Besides all, Ankara-Anamur and Mersin-Mut highway projects are on the agenda. Correspondingly, the only railway route is proposed between Mersin-Mut-Karaman in the plan. The proposed highway crossing the Bakırçay Basin from Çandarlı to Dikili until Dardanelle Bosphorus and the Northern Marmara Highway passing through Anatolian Side of Istanbul basin are some major projects that will prompt the dominance of motor vehicles. Moreover, the route decision of light rail system from Aliağa to Bergama and far brings forth the risk of the centre of Bakırçay Basin to sprawl frantically over the plain in the south direction. As a result, reinforcing simply accommodation, highway, marina and airport facilities cannot meet the needs of tourism sector and other local economies in the basin scales. Therefore, the main issue should be how to manage tourism and other economic resources rather than the facilities.

\section{EVALUATION - FUNDAMENTALS OF BASIN-SCALE APPROACH AS A STRATEGY OF SMART PLANNING}

The quest for solutions to global environmental problems that began in the 1970s has been the focus of many discussions on the international level. As a result of these searches, the application and measurement tools related to the concept of "sustainability", that were described in concrete terms for the first time with the Brundlant Report in 1987, have given a significant respect to the studies in the following years. This is the search for operationalization in the field of urban planning with the creation of "healthy settlements and environments" conditions that are taken up by the Stockholm Summit in 1972 and the 
Habitat II in Istanbul in 1996. The principles-based tools of sustainability are increasingly on the verge of settlement and even more holistic approaches such as the regional priorities anticipating the contribution of planning discipline come into prominence [18].

In the international literature to develop measures against the climate change in the field of planning; it is a priority issue to develop place-based principles that are required by the planning for all basins of the country (not by similar methods). To be able to demonstrate "natural and cultural diversity" in different basins can encourage the researches for all basins of the Country that can also reveal an opportunity to avoid the risk of making mistakes with similar approaches.

Conventional planning covers analysis, plan, practice and evaluation milestones. However, they are criticized of certain rigidity, formalization and linear thought character, which cannot confront the challenges in sustainability. Ignorance of economic sectorial impacts on each other is one of the main reasons in this gap. Whereas, any type of investments in an area or region can display positive and/or negative impacts on the activities, potentials, resources and vice versa. Consequently, a substantial planning and management approach providing an alternative control mechanism and collaboration between all types of stakeholders will be a base for leading sustainable common future. The adaptation of preservation and utilization of resources together in an integrated approach that co-organizes the common future of economic activities in a holistic manner would help smart planning and management to be assisted in terms of sustainable development.

The geographical structure and cultural, folkloric characteristics, population size, location (plain, hillside, mountain, forest, river or sea coast etc.) and orientations of the settlements, their relations, interactions and partnerships with each other, qualification of the centres, proximity to regional service areas or facilities presents authentic diversities under the influence of site-specific dynamics that will shape the planning decisions throughout the Göksu, Bakırçay and Istanbul Anatolian Side basins [19]. This suggests that place-based principles should be developed for each of the holistic and specific sub-regions of different basins. Therefore, the Bakırçay, Göksu and Anatolian Side of Istanbul basins indicate alternative types of potentials to be specialized in sustainable economy aiming to develop socio-economic life and to improve the environmental quality concurrently. The sample basins give hints about the perspectives and deficiencies in the provision of smart planning and management together with the investment and infrastructure integration.

Keeping in mind the objective of this paper that aims to reveal a systematic approach to basins in order to achieve sustainability, protection and development through smart planning and the designations of the study declared at the beginning, a strategic framework for the required principles are benefited:

1. Essential role of water-soil-vegetation integrity of life cycle:

- natural structure + natural heritage/natural peculiarities to be protected/natural preservation zones (forest, agricultural land, endemic plant zones, dunes, accommodation and breeding area of birds, habitats for marine organisms), human activities;

- demography and type of economic structures, social structure, property and land values, built-up area, land use, morphological features, morphological typology, cultural and historical heritage.

2. Controllable and observable scale for the management of problems and risks:

- global climate change and sea-level rise;

- mega projects, for instance; railways at South and West Anatolia, new highways, Akkuyu Nuclear Power Plant, İzmir-Çandarlı North Aegean 
Port, new towns at the Istanbul basins due to $3^{\text {rd }}$ Airport at the Black Sea coast and $3^{\text {rd }}$ Bridge and North Marmara Highway,

- $\quad$ pressure on eco-system (loss of forests and agricultural lands, occupation and contamination of basins and river beds, occupation on pervious rock, occupation at geological and morphological risk area, (holiday) housing sites along coastline),

- lack of database and monitoring, lack of biological treatment plant, sea outfall, integration of marine transport facilities with other transportation modes.

3. Opportunity to determine capacities and thresholds based on cross-sector interaction in terms of the characteristics of local natural environment and interactions among natural environment (geography), economic and demographic potentials of basins to define planning criteria for smart planning:

- landscape, "waterfront", long term measures to preserve resources, cultural heritage, identity, determination of land use in accordance with carrying capacity of eco-system, functions specific to the sub-zones of defined basin, functions important and necessary for the basin, negative reciprocal effects, determination of concrete proposals for the specific location, establishment of a responsive, participatory and consensus based management model;

- definition of implementation tools both legal and institutional (plans, projects, official interests, opinions, visions)

4. Regulation to achieve co-existence of communities and settlement system pattern sharing fate of union as particular bases for implementing holistic basin-scale as a strategy of smart planning:

- planning system specific to defined basin, preserving vulnerable eco-systems, prevention and control of pollution, implementation of disaster management, continuous monitoring and evaluation to enable basin-specific planning, protection and investment process / recovery of defined basin;

- fully assessing in the scope of protection, national, regional and local level compatible with each other and planning principles should be subject to legal regulations (legislation) and institutional structure.

Integrated management to be adopted by all actors should balance conservation \& utilization principles restricting private usage instead the statement of public priority as a basis. As a result, compelling impacts of climate change once again verify and remind us the significance of interdisciplinary and holistic political decision making and modules that should involve all sectors in the strategy of smart planning for future.

\section{REFERENCES}

[1] Yenen, Z., Örnek, E., Hamamcıŏlu, C., Seçkin, E., İnal Çekiç, T. \& Yerliyurt, B., Urban Development and Management for Tourism in Conservation Areas - Case of Bergama. Scientific and Technological Research Council of Turkey, 2005-2006.

[2] Yakar, H.B., Yenen, Z., Erkan, N. \& Hamamcığlu, C., Re-defining the Measures of the Hierarchy of Settlements'. Scientific Research Project Coordination of Yıldız Technical University, 2010-2013.

[3] Kılıç, A. et al. The Development of a Proposal and Planning Model to Adapt Environmental Principal Plan of Metropolitan City of Istanbul (scaled 1:100 000) to the Coastal Areas, Y1ldı Technical University, 2013. 
[4] Department of Urban and Regional Planning in Faculty of Architecture, Yildiz Technical University, Istanbul, 2005-2013.

[5] Hamamcioğlu, C. \& Yenen, Z., The potentials of integrated water basin-based approach for sustainable tourism. Sustainability Issues and Challenges in Tourism, Boğaziçi University, Istanbul, Turkey, pp. 23-28, 2013.

[6] Yenen, Z. \& Hamamcioğlu, C., Evolution of hierarchy of settlements in river-basin scale towards climate change. Int. J. Global Warming, 11(2), pp. 182-200, 2017.

[7] Stocker, T.F. et al., The Physical Science Basis. Contribution of Working Group I to the Fifth Assessment Report of the Intergovern- mental Panel on Climate Change, IPCC-Panel on the Climate Change, Cambridge University Press: Cambridge, United Kingdom and New York, p. 1535, 2013.

[8] Turkey's National Climate Change Adaptation Strategy and Action Plan, T.R. Ministry of Environment and Urbanization General Directorate of Environmental Management, Department of Climate Change, Ankara, 2011.

[9] Türkiye İklim Değişikliği 6. Ulusal Bildirimi (6th National Declaration on Climate Change in Turkey), T.R. Ministry of Environment and Urbanization, Ankara, 2016.

[10] Turkey's Fifth National Communication Under the UNFCCC, T.R. Ministry of Environment and Urbanization General Directorate of Environmental Management, Ankara, pp. 170-171, 2013.

[11] Kuleli, T., City-based risk assessment of sea level rise using topographic and census data for the Turkish coastal zone. Estuaries and Coasts, 33, pp. 640-651, 2010.

[12] Kuleli, T., Senkal, O. \& Erdem, M., National assessment of sea level rise using topographic and census data for Turkish coastal zone. Environmental Monitoring and Assessment, 156(4), pp. 425-434, 2009.

[13] Alpar, B., Vulnerability of Turkish coasts to accelerated sea-level rise. Geomorphology, 107, pp. 58-63, 2009.

[14] Demirkesen, A.C., Evrendilek, F. \& Berberoglu, S., Quantifying coastal inundation vulnerability of Turkey to sea-level rise. Environmental Monitoring Assessment, 138(1), pp. 101-106, 2008.

[15] TÜİK - Turkish Statistics of Institution, Population Statistics, 2015.

[16] IEA-International Energy Agency, (2015) World Energy Statistics 2015: CO2 Emissions from Fuel Combustion Highlights, online. http://www.iea.org/.

Accessed on: 20 Jan. 2017.

[17] Kerestecioğlu, F., Tümer Özkan, D.B, Hamamcıoğlu, C., Yerliyurt, B., Sakınç, E. \& Hafızoğlu, T., Reducing cooling and heating loads in existing residential buildings in the context of building envelope: Beykoz-Kanlıca. MEGARON E-Journal, 10(4), pp. 451-469, 2015.

[18] United States Green Building Council, LEED-ND for Neighborhood Development, the Congress for the New Urbanism Natural Resources Defense Council and the United States Green Building Council, Washington, 2009.

[19] Yakar, H. \& Erkan, N., Kır ve kent kavramı ile tanımlanamayan (bulanık) yerleşmeler: Göksu Havzası örneği (Unidentified -fuzzy- settlements with the concept of rural and urban: case of Göksu Basin). Kent Yönetimi ve Planlama. 37. Dünya Şehircilik Günü Kolokyumu, Dokuz Eylül Üniversitesi, DESEM, İzmir, pp. 54-55, 2013. 